\title{
Dopaminergic modulation of grooming behavior in virgin and pregnant rats
}

A.P. Serafim and L.F. Felicio
Departamento de Patologia, Faculdade de Medicina Veterinária, Universidade de São Paulo, São Paulo, SP, Brasil

\section{Correspondence \\ L.F. Felicio \\ Departamento de Patologia \\ Faculdade de Medicina Veterinária \\ Universidade de São Paulo \\ Av. O rlando Marques Paiva, 87 \\ 05508-900 São Paulo, SP \\ Brasil \\ Fax: + 55-11-3818-7829 \\ E-mail: Ifelicio@usp.br \\ Research supported by FAPESP \\ (No. 96/4193-0) and CNPq \\ (No. 520234/96) grants to \\ L.F. Felicio. A.P. Serafim was \\ the recipient of FAPESP and CNPq \\ fellowships.}

Received May 7, 2001

Accepted September 4, 2001

\section{Abstract}

Dopamine receptors are involved in the expression of grooming behavior. The pregnancy-induced increase in self-licking observed in rats is important for mammary gland development and lactation. This study focuses on the role of dopamine receptor subtypes in grooming behavior of virgin and pregnant female rats. General and mammary gland grooming were measured in virgin rats treated with $0.25 \mathrm{mg} / \mathrm{kg}$ of the D1-like agonist SKF-81297 and antagonist SKF-83566 and the D2-like agonist lisuride and antagonist sulpiride. The effects of 0.01 and $0.25 \mathrm{mg} / \mathrm{kg}$ doses of the same agonists and antagonists were evaluated in pregnant rats as well. In virgin animals both SKF-83566 and sulpiride treatments significantly reduced the time spent in general grooming, while none of the dopamine agonists was able to significantly change any parameter of general grooming. Time spent in grooming directed at the mammary glands was not affected significantly by any of the drug treatments in virgin rats. All drugs tested significantly decreased the frequency of and the time spent with general grooming, while SKF-81297 treatment alone did not significantly reduce the duration of mammary gland grooming in pregnant rats. These data show that in female rats the behavioral effects of D1like and D2-like dopamine receptor stimulation and blockade differ according to physiological state. The results suggest that dopamine receptors may play specific roles modulating grooming behavior in pregnant rats. Since grooming of the mammary gland during pregnancy may influence lactation, this aspect is relevant for studies regarding the perinatal use of dopamine-related drugs.
Key words

- Self-licking

- Lisuride

- SKF-81297

- SKF-83566

- Sulpiride

- Mammary gland

- Prolactin

- Dopamine

\section{Introduction}

Almost all animal species spend a significant part of their time in grooming behavior (1). Although various neurotransmitters can modulate the expression of this behavior $(2,3)$, dopamine is particularly involved $(4,5)$. Lesions in brain regions rich in dopaminergic inputs influence the implementation of grooming syntax (6). Moreover, in rodents grooming behavior is differently modulated by stimulation and blockade of dopamine receptor subtypes (5,7-9), sex (10) and reproductive state (11). Grooming behavior is under the influence of the endocrine milieu $(4,12)$. During pregnancy female rats change their grooming patterns, tending to lick their mammary glands more than prior to pregnancy $(11,13)$. This in turn has been shown to be important for mammary gland development and lactation (14). Researchers have shown that dopamine is involved in both the 
onset and maintenance of maternal care $(15,16)$. There are two pharmacologically distinct dopamine receptor families, D1-like and D2-like (17). These receptors are represented by at least five different proteins; $D_{1}$ and $\mathrm{D}_{5}$ are subtypes of D1-like receptors, while $\mathrm{D}_{2}, \mathrm{D}_{3}$ and $\mathrm{D}_{4}$ are subtypes of D2-like receptors (18). While it is possible to differentiate between the two dopamine receptor subfamilies, the different members within each subfamily cannot be distinguished by pharmaceutical means. Pharmacological manipulations of the dopaminergic systems during pregnancy can influence both maternal $(15,16)$ and offspring behavior (19-24). The aim of the present study was to investigate the role of D1-like and D2-like dopamine receptor families in grooming behavior of virgin and pregnant rats. Our working hypothesis was that in female rats the modulatory role of each of these receptor families in grooming behavior changes according to reproductive state. Since frequently small and large doses of dopamine-related drugs have different effects, pregnant rats were challenged with two doses.

\section{Material and Methods}

\section{Animals}

At least one month before the behavioral tests, adult virgin female Wistar rats from our own colony weighing 180-220 $\mathrm{g}$ at the beginning of the experiments were individually housed in polypropylene cages ( $45 \times 25$ x $20 \mathrm{~cm}$ ) on a controlled light-dark cycle (lights on from 6:00 to 18:00) at a temperature of $22 \pm 3^{\circ} \mathrm{C}$. Water and food were available ad libitum. Rats were kept virgin for experiment 1 or were mated with males (experiment 2). The day sperm was observed in the vaginal lavage was designated day 1 of pregnancy. The animals used in this study were maintained in accordance with the guidelines of the Committee on Care and Use of Laboratory Animal Resources, Na- tional Research Council, USA.

\section{Drugs}

Drugs were the D1-like agonist SKF81297 and antagonist SKF-83566 and the D2-like agonist lisuride and antagonist sulpiride, all obtained from RBI (Natick, MA, USA). They were diluted in saline and administered subcutaneusly $(s c)$ in a volume of $1.0 \mathrm{ml} / \mathrm{kg}$.

\section{Measurements and observations}

Grooming behavior was videotaped during 30-min test sessions on days 7, 8 and 9 of pregnancy. Virgin animals were observed on each testing day as well. To minimize possible circadian influences, observations of animals from different groups were intermixed; observations began at 8:00 am and animals were placed in the same order every day. Each rat was videotaped under room light in her own cage with a glass cover. Two habituation sessions were held on the days preceding the day of the first testing session. Each pregnant animal was tested three times, being injected with a different dose of the drug each time. The days of each drug dose were randomly assigned to each animal. Each drug dose was tested on at least six animals. Self-licking was recorded according to the body region to which it was confined. Head, forepaws, shoulders and upper back were recorded as general grooming, while nipple lines, genital and pelvic regions were considered as mammary gland grooming. The frequency and duration in seconds of each of these behavioral categories were recorded during individual 30-min sessions.

\section{Experiment 1. Effects of stimulation and blockade of dopamine receptors on groom- ing behavior of virgin female rats}

Virgin rats were injected $s c$ with saline or $0.25 \mathrm{mg} / \mathrm{kg}$ of SKF-81297, SKF-83566, 
lisuride or sulpiride and tested for grooming behavior for $30 \mathrm{~min}$ starting $10 \mathrm{~min}$ after drug injection.

\section{Experiment 2. Effects of stimulation and blockade of dopamine receptors on grooming behavior of pregnant female rats}

Pregnant rats were injected $s c$ with saline, 0.01 or $0.25 \mathrm{mg} / \mathrm{kg}$ of SKF-81297, SKF83566 , lisuride or sulpiride and tested for grooming behavior for $30 \mathrm{~min}$ starting 10 min after drug injection.

\section{Statistical analysis}

Statistical comparisons between two groups were made using the Student $t$-test (Experiment 1). One-way analysis of variance (ANOVA) followed by the TukeyKramer test was used to compare grooming behavioral data when various doses were used (Experiment 2). A probability of $\mathrm{P}<0.05$ was considered significant for all comparisons made.

\section{Results}

Only the dopamine receptor antagonists SKF-83566 and sulpiride significantly reduced the time spent in general grooming by virgin rats $(\mathrm{P}<0.05$; Table 1$)$, while none of the dopamine receptor agonists or antagonists significantly influenced the time spent in mammary grooming by virgins (Table 1 ). General grooming displayed by pregnant rats was significantly reduced by previous treatment with the lower dose $(0.01 \mathrm{mg} / \mathrm{kg})$ of SKF-81297 $(\mathrm{F}(2,62)=15.7 ; \mathrm{P}<0.05)$. Both the 0.01 and $0.25 \mathrm{mg} / \mathrm{kg}$ doses of lisuride $(\mathrm{F}(2,54)=41.0 ; \mathrm{P}<0.05), \mathrm{SKF}-83566$ $(\mathrm{F}(2,62)=38.2 ; \mathrm{P}<0.05)$ and sulpiride $(\mathrm{F}(2,62)=28.1 ; \mathrm{P}<0.05)$ significantly reduced the time for general grooming in pregnant rats (Table 2). Both doses of the D1-like antagonist SKF-83566 $(\mathrm{F}(2,62)=9.5$; $\mathrm{P}<0.05$; Figure 1), the D2-like agonist lisuride
$(\mathrm{F}(2,54)=11.3 ; \mathrm{P}<0.05)$ and the $\mathrm{D} 2$-like antagonist sulpiride $(\mathrm{F}(2,62)=6.4 ; \mathrm{P}<0.05)$ significantly reduced the time spent in mammary gland grooming by pregnant rats (Figures 1 and 2). None of the treatments with the D1-like agonist SKF-81297 significantly influenced the time spent in mammary gland grooming by pregnant rats (Figure 1). The frequency of grooming was not significantly affected by any drug treatment in virgin rats (Table 3). Both the 0.01 and $0.25 \mathrm{mg} / \mathrm{kg}$ doses of SKF-81297 $(\mathrm{F}(2,62)=12.03$;

Table 1. Effects of stimulation and blockade of dopamine receptors on time (seconds) spent in grooming behavior by virgin rats.

\begin{tabular}{lcc}
\hline & $\begin{array}{c}\text { General } \\
\text { grooming }\end{array}$ & $\begin{array}{c}\text { Mammary gland } \\
\text { grooming }\end{array}$ \\
\hline Saline (24) & $58 \pm 3.7$ & $8 \pm 2.7$ \\
SKF-81297 (6) & $50 \pm 5.8$ & $5 \pm 2.2$ \\
SKF-83566 (6) & $32 \pm 6.6^{*}$ & $9 \pm 1.7$ \\
Lisuride (6) & $50 \pm 5.8$ & $7 \pm 3.1$ \\
Sulpiride (6) & $40 \pm 6.9^{*}$ & $5 \pm 2.5$ \\
\hline
\end{tabular}

Animals were treated with saline or $0.25 \mathrm{mg} / \mathrm{kg} \mathrm{sc}$ of one of the drugs and observed for $30 \mathrm{~min}$ for grooming behavior. Data are reported as means \pm SEM. The number of animals is given in parentheses. $* \mathrm{P}<0.05$ compared to the saline group (Student t-test).

Table 2. Effects of stimulation and blockade of dopamine receptors on time spent in general grooming behavior by pregnant rats.

\begin{tabular}{lccc}
\hline & \multicolumn{3}{c}{ Dose $(\mathrm{mg} / \mathrm{kg})$} \\
\cline { 2 - 4 } & 0.00 & 0.01 & 0.25 \\
\hline Saline & $200 \pm 104$ & - & - \\
SKF-81297 & - & $83 \pm 6.8^{*}$ & $175 \pm 7.4$ \\
SKF-83566 & - & $71 \pm 8.2^{*}$ & $49 \pm 6.6^{*}$ \\
Lisuride & - & $29 \pm 10.3^{*}$ & $0 \pm 0.0^{*}$ \\
Sulpiride & - & $109 \pm 15.1^{*}$ & $52 \pm 4.8^{*}$ \\
\hline
\end{tabular}

Data are reported as means \pm SEM. $\mathrm{N}=45$ for the saline group and $\mathrm{N}=10$ for all other groups. $* \mathrm{P}<0.05$ compared to the saline group (ANOVA followed by the Tukey-Kramer test). 
$\mathrm{P}<0.05)$, lisuride $(\mathrm{F}(2,54)=29.75 ; \mathrm{P}<0.05)$, SKF-83566 $(\mathrm{F}(2,62)=12.16 ; \mathrm{P}<0.05)$ and sulpiride $(\mathrm{F}(2,62)=20.17 ; \mathrm{P}<0.05)$ significantly reduced the frequency of general groom-

Figure 1. Effects of acute sc treatment with the D1-like receptor agonist SKF-81297 (A) and antagonist SKF-83566 (B) on the duration of self-grooming of the mammary glands in 7-9-day pregnant rats. $* \mathrm{P}<0.05 \mathrm{com}$ pared to the saline-treated group (ANOVA followed by the TukeyKramer test).
Figure 2. Effects of acute sc treatment with the D2-like receptor agonist lisuride $(\mathrm{A})$ and antagonist sulpiride (B) on the duration of self-grooming of the mammary glands in 7-9-day pregnant rats. $* \mathrm{P}<0.05 \mathrm{com}-$ pared to the saline-treated group (ANOVA followed by the TukeyKramer test).
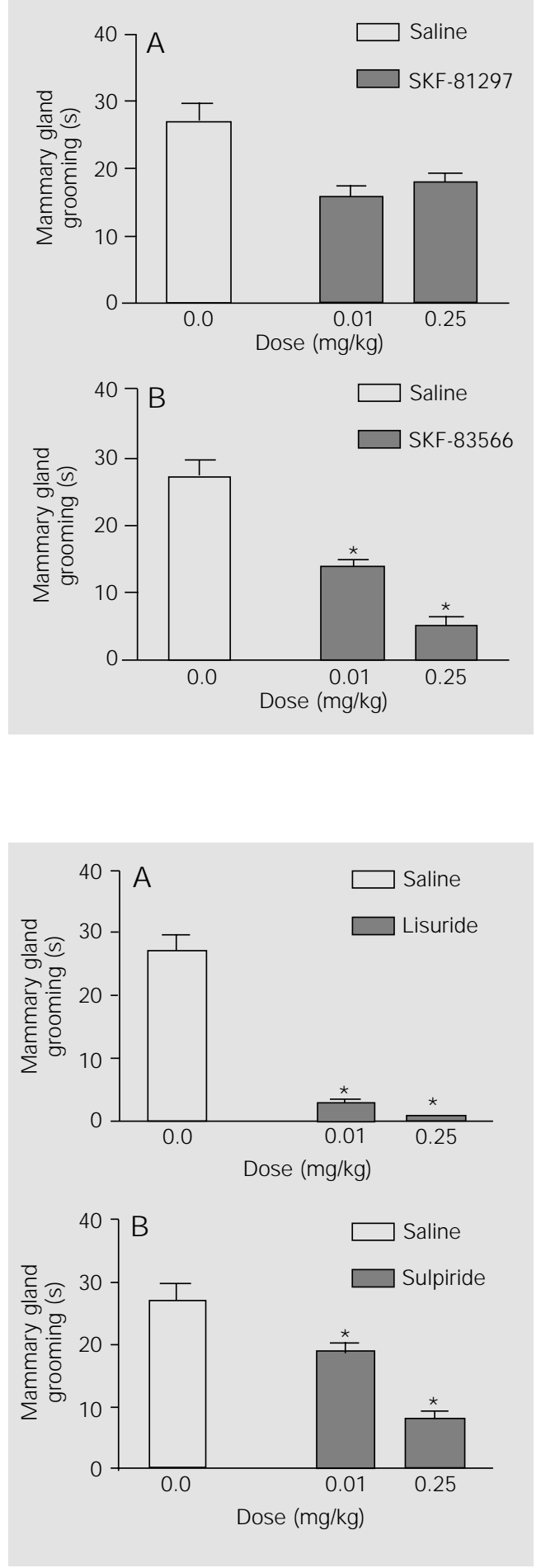

ing displayed by pregnant rats (Table 3 ).

\section{Discussion}

The patterns of grooming behavior are not the same in virgin and pregnant rats. Our data confirm this finding and suggest that dopaminergic modulation of grooming differs according to reproductive physiological state as well. The fact that the effects of pharmacological manipulations of dopaminergic systems on grooming behavior were more frequent in pregnant than in virgin rats suggests that grooming displayed by females during pregnancy is more sensitive to dopaminergic modulation. This may also suggest that dopaminergic-mediated neurotransmission plays a more marked role in grooming in pregnant than in non-pregnant rats. Female reproductive state can influence dopamine-related hormones $(25,26)$, behavior $(27,28)$ and cognition $(29,30)$. The fact that only the dopamine receptor antagonists influenced the general grooming displayed by virgin rats suggests that 1) dopaminergic neurotransmission is important for the expression of grooming behavior, and 2) dopaminergic overstimulation does not affect grooming in virgin rats. Neither dopamine receptor agonist-induced overstimulation nor dopamine receptor antagonist-induced disruption of neurotransmission was able to induce mammary gland grooming in virgin rats, suggesting that this specific kind of grooming is not under dopaminergic control in virgin rats. Alternatively, since mammary gland grooming expression is robust only during pregnancy $(11,14)$ a possible role for dopaminergic neurotransmission in this behavior can be investigated only during the physiological state in which the behavior is being expressed.

Low and high doses of the dopamine agonists and antagonists usually produce opposite behavioral effects. This was not observed for mammary gland grooming. Changes in motor activity (exploratory be- 
Table 3. Effects of stimulation and blockade of dopamine receptors on frequency of grooming behavior in virgin and pregnant rats.

\begin{tabular}{|c|c|c|c|c|}
\hline \multirow{2}{*}{ Drug (mg/kg) } & \multicolumn{2}{|c|}{ General } & \multicolumn{2}{|c|}{ Mammary gland } \\
\hline & Virgin & Pregnant & Virgin & Pregnant \\
\hline Saline & $4 \pm 1.0(24)$ & $6 \pm 0.3(45)$ & $1 \pm 0.3(24)$ & $2 \pm 0.2(45)$ \\
\hline \multicolumn{5}{|l|}{ SKF-81297 } \\
\hline 0.01 & - & $3 \pm 0.2^{*}(10)$ & - & $2 \pm 0.3(10)$ \\
\hline 0.25 & $3 \pm 0.6$ & $4 \pm 0.3^{*}(10)$ & $1 \pm 0.2(6)$ & $2 \pm 0.2(10)$ \\
\hline \multicolumn{5}{|l|}{ Lisuride } \\
\hline 0.01 & - & $2 \pm 0.4^{*}(10)$ & - & $0 \pm 0.2^{*}(10)$ \\
\hline 0.25 & $4 \pm 11(6)$ & $0 \pm 0.0^{*}(10)$ & $1 \pm 0.2(6)$ & $0 \pm 0.0^{*}(10)$ \\
\hline \multicolumn{5}{|l|}{ SKF-83566 } \\
\hline 0.01 & - & $4 \pm 0.5^{*}(10)$ & - & $2 \pm 0.2(10)$ \\
\hline 0.25 & $3 \pm 0.9(6)$ & $3 \pm 0.4^{*}(10)$ & $1 \pm 0.4(6)$ & $1 \pm 0.2^{*}(10)$ \\
\hline \multicolumn{5}{|l|}{ Sulpiride } \\
\hline 0.01 & - & $3 \pm 0.5^{*}(10)$ & - & $2 \pm 0.2(10)$ \\
\hline 0.25 & $3 \pm 0.7(6)$ & $2 \pm 0.3^{*}(10)$ & $1 \pm 0.3(6)$ & $2 \pm 0.2(10)$ \\
\hline
\end{tabular}

havior) induced by the drugs may have interfered with these results. Alternatively, since during lactation possibly the expression of mammary gland grooming achieves its physiological highest, any pharmacological challenge would only induce inhibitory effects on this behavior.

Differently from virgin animals, in pregnant rats all pharmacological dopaminergic manipulations induced decreases in the time spent in general grooming. Nevertheless, the drug-induced decrease varied according to the dose. The D1-like agonist SKF-81297 reduced the time spent in general grooming only at the lowest dose. The optimum behavioral effect of both dopamine receptor agonists and antagonists can be induced by small or presynaptic doses (31). Both high and low doses of dopamine receptor agonists and antagonists can be behaviorally effective $(31,32)$. Differently from what occurred with the expression of general grooming, these behaviors may have competed with and eventually prevailed over mammary gland grooming in pregnant animals. Future studies will focus on a possible dopaminergic modulation of grooming behavior in other physiological states such as lactation or reproductive senility.

The present results show that pharmacological manipulations of dopaminergic neurotransmission modulate the expression of grooming behaviors in both virgin and pregnant rats. Concerning pregnant rats, these data may have implications for studies involving perinatal pharmacology and toxicology in which dopaminergic transmission is altered during pregnancy. 


\section{References}

1. MacFarland CG \& Reeder WG (1974). Cleaning symbiosis involving Galapagos tortoises and two species of Darwin's finches. Zeitschrift für Tierpsychologie, 34: 464-483.

2. Moody TW, Merali Z\& Crawley J N (1988). The effects of anxiolytics and other agents on rat grooming behavior. In: Colbem DL $\&$ Gispen WH (Editors), Neural Mechanisms and Biological Significance of Grooming Behavior. Annals of the New York Academy of Sciences, 525: 281-290.

3. Traber J , Spencer DG, Glaser T \& Gispen WH (1988). Actions of psychoactive drugs on ACTH- and novelty-induced behavior in the rat. In: Colbern DL \& Gispen WH (Editors), Neural Mechanisms and Biological Significance of Grooming Behavior. Annals of the New York Academy of Sciences, 525: 270-280.

4. Cools AR, Spruijt BM \& Ellenbroek BA (1988). Role of central dopamine in ACTHinduced grooming behavior in rats. In: Colbern DL \& Gispen WH (Editors), Neural Mechanisms and Biological Significance of Grooming Behavior. Annals of the New York Academy of Sciences, 525: 338-350.

5. Drago F, Contarino A \& Busa L (1999). The expression of neuropeptide-induced excessive grooming behavior in dopamine D1 and D2 receptor-deficient mice. European J ournal of Pharmacology, 365: 125131.

6. Cromwell HC \& Berridge KC (1996). Implementation of action sequences by a neostriatal site: a lesion mapping study of grooming syntax. Journal of Neuroscience, 16: 3444-3458.

7. Starr BS \& Starr MS (1987). Behavioural interactions involving D1 and D2 dopamine receptors in non-habituated mice. Neuropharmacology, 26: 613-619.

8. Starr BS \& Starr MS (1986). Differential effects of dopamine D1 and D2 agonists and antagonists on velocity of movement, rearing and grooming in the mouse. Implications for the roles of D1 and D2 receptors. Neuropharmacology, 25: 455-463.

9. Starr BS \& Starr MS (1986). Grooming in the mouse is stimulated by the dopamine D1 agonist SKF 38393 and by low doses of the D1 antagonist SCH 23390, but is inhibited by dopamine D2 agonists, D2 antagonists and high doses of $\mathrm{SCH}$ 23390. Pharmacology, Biochemistry and Behavior, 24: 837-839.

10. Diaz-Veliz G, Butron S, Benavides M, Dussaubat N \& Mora S (2000). Gender, estrous cycle, ovariectomy, and ovarian hormones influence the effects of diazepam on avoidance conditioning in rats. Pharmacology, Biochemistry and Behavior, 66: 887-892.

11. Roth LL \& Rosenblatt JS (1966). Mammary glands of pregnant rats: development stimulated by licking. Science, 151: 1403-1404.

12. Drago F \& Lissandrello CO (2000). The "low-dose" concept and the paradoxical effects of prolactin on grooming and sexual behavior. European J ournal of Pharmacology, 405: 131-137.

13. Roth LL \& Rosenblatt J S (1967). Changes in self-licking during pregnancy in the rat. J ournal of Comparative and Physiological Psychology, 63: 397-400.

14. Roth LL \& Rosenblatt J S (1968). Self-licking and mammary development during pregnancy in the rat. J oumal of Endocrinology, 42: 363-378.

15. Kinsley $\mathrm{CH}$, Turco $D$, Bauer $A$, Beverly $M$, Wellman J \& Graham AL (1994). Cocaine alters the onset and maintenance of matemal behavior in lactating rats. Pharmacology, Biochemistry and Behavior, 47: 857-864.

16. Silva MRP, Bemardi MM \& Felicio LF (2001). Effects of dopamine receptor antagonists on ongoing matemal behavior in rats. Pharmacology, Biochemistry and Behavior, 68: 461-468.

17. Seeman $P$ (1980). Brain dopamine receptors. Pharmacological Reviews, 32: 229287.

18. Sokoloff P \& Schwartz J C (1995). Novel dopamine receptors half a decade later. Trends in Pharmacological Sciences, 16: 270-275.

19. Nasello AG \& Ramirez OA (1978). Openfield and Lashley III maze behaviour of the offspring of amphetamine-treated rats. Psychopharmacology, 58: 171-173.

20. Cuomo V, Cagiano R, Mocchetti I, Coen E, Cattabeni F \& Racagni G (1983). Behavioural and biochemical effects in the adult rat after prolonged postnatal administration of clozapine. Psychopharmacology, 81: 239-243.

21. Hull EM, Nishita JK \& Bitran D (1984). Perinatal dopamine related drugs demasculinize rats. Science, 224: 1011-1013.
22. Felicio LF, Palermo-Neto J \& Nasello AG (1989). Perinatal bromopride treatment: Effects on sexual behavior of male and female rats. Behavioral and Neural Biology, 52: 145-151.

23. Felicio LF, Palermo-Neto J \& Nasello AG (1989). Perinatal bromopride treatment: Effects on motor activity and stereotyped behavior of offspring. Physiology and Behavior, 45: 1081-1085.

24. Nasello AG \& Felicio LF (1990). Avoidance behavior, prolactin, HVA and DOPAC in offspring of bromopride treated rats. Pharmacology, Biochemistry and Behavior, 37: 571-575.

25. Bridges RS, Felicio LF, Pellerin LJ , Stuer AM \& Mann PE (1993). Prior parity reduces post-coital diurnal and nocturnal prolactin surges in rats. Life Sciences, 53: 439-445.

26. Felicio LF, Florio J C, Sider LH, CruzCasallas PE \& Bridges RS (1996). Reproductive experience increases striatal and hypothalamic dopamine levels in pregnant rats. Brain Research Bulletin, 40: 253-256.

27. Silva MRP, Bemardi MM, Nasello AG \& Felicio LF (1997). Influence of lactation on motor activity and elevated plus maze behavior. Brazilian J ournal of Medical and Biological Research, 30: 241-244.

28. Kinsley $\mathrm{CH}$, Madonia L, Gifford GW, Tureski K, Griffin GR, Lowry C, Williams J, Collins J, McLearie $\mathrm{H} \&$ \& Lambert KG (1999). Motherhood improves learning and memory. Nature, 402: 137-138.

29. Liu D, Diorio J, Day J C, Francis DD \& Meaney MJ (2000). Maternal care, hippocampal synaptogenesis and cognitive development in rats. Nature Neuroscience, 3: 799-806.

30. Maestripieri D \& Megna NL (2000). Hormones and behavior in rhesus macaque abusive and nonabusive mothers. 1. Social interactions during late pregnancy and early lactation. Physiology and Behavior, 71: 35-42.

31. Nasello AG, Tieppo CA \& Felicio LF (1995). Apomorphine-induced yawning in the rat: influence of fasting and day time. Physiology and Behavior, 57: 967-971.

32. Felicio LF, Nasello AG \& Palermo-Neto J (1987). Dopaminergic supersensitivity after long-term bromopride treatment. Physiology and Behavior, 41: 433-437. 